\title{
The influence of treated wastewater from the Lodz city agglomeration on the ice regime and water temperature of the Ner river
}

\begin{abstract}
The study attempts to answer the following question: Does human impact contribute to changes recorded in the Ner river ice regime? In replying to this question, data on water consumption in Lodz (Łódź) (a city in central Poland) in 1951-2017 were used, as well as observations of ice cover and all ice phenomena for the same period. The ice regime and water temperature of the river have changed over the past 70 years. The changes result not only from changes caused by global warming but also from additional fluctuations in this temperature as determined by changes in the quantity and quality of wastewater discharged into the river from the Lodz city agglomeration. The frequency of ice phenomena in the river decreased, and their duration dropped by almost half. This tendency was compounded by a decrease in number of days with ice phenomena, which in turn was caused by a rapid increase in the amount of waste and thermally polluted waters supplied from Lodz. The river water temperature has now stopped increasing. The course of the river ice regime now resembles that of a natural watercourse again.
\end{abstract}

Keywords

Human impact • ice phenomena $\bullet$ river regime $\cdot$ river water temperature Lodz (Łódź)

(C) University of Warsaw - Faculty of Geography and Regional Studies

\section{Introduction}

Until recently, because of climatic conditions in Poland, the occurrence of various river ice types was a common but periodic phenomenon. Having different intensities and durations, such phenomena used to happen annually in most rivers of Poland (Gołek 1961). They were also considered typical properties of the river regime, which were indicative of being affected by the key features of Poland's continental climate in winter. The ice phenomena in Polish rivers had different forms. Those most often noted and examined were: frazil, border ice and ice cover, while less common were frazil and freeze-up ice jams. Individual particular phenomena usually appeared in rivers in so-called ice cycles. At the beginning of the cycle, border and anchor ice usually occurred, then ice floe appeared and sometimes, at the end of the cycle, ice jams. Such cycles were sometimes completed; however, more often only part of the cycle was observed. Moreover, the sequence of individual ice phenomena varied. As a result, the number and nature of ice cycles differed between different years and from river to river.

Similarly, the durations and pause times between them were also different and depended on the dates of the beginning and the end of ice phenomena and ice cover (Prowse 2001; Pawłowski et al. 2017). Today, as a result of warming and a rise in river water temperature during winter, ice phenomena on Polish rivers are less frequent, often episodic, and complete ice cycles almost never happen.

Many years (1984-2018) of satellite research (Landsat programme) have shown that in winter (Dec, Jan, Feb) iced stretches of the rivers as a percentage of full river length was temporally and spatially variable in Poland. The percentages
Adam Bartnik $\mathbb{C}$, Paweł Jokiel 수

Department of Hydrology and Water Management, Institute of Climatology and Hydrology, Faculty of Geographical Sciences, University of Lodz, Poland e-mail: adam.bartnik@geo.uni.lodz.pl e-mail: pawel.jokiel@geo.uni.lodz.pl

Received: 3 July 2020 Accepted: 4 May 2021 have changed within significantly wide limits in the period: from 0\% (Baltic Coastland) to almost 100\% (Carpathian Mountains, Masurian Lakeland) (Yang et al. 2020). The maps presented in Yang et al.'s study also show that in the years 2008-18, in comparison to the period 1988-94, the percentage was clearly smaller: from $5-10 \%$ in the Masurian Lakeland and Mazovia, to $10-15 \%$ in Greater Poland and the Carpathian Mountains. The authors thereof declare that the changes in Europe (including Poland) are among the largest in the world.

Magnuson et al. (2000) demonstrated that the mean date of ice cover appearance on rivers of the northern hemisphere at the beginning of the $21^{\text {st }}$ century moved forward by ca 5.7 days in comparison with the beginning of the $20^{\text {th }}$ century, while the mean date when the ice cover disappears moved backward by ca 6.3 days. Thus, the duration of this phenomena shortened by more than 12 days. It has also been shown that the changes correspond to an increase in mean winter air temperature of about $1.2{ }^{\circ} \mathrm{C}$ per 100 years. In Baltic states, the observed trends of ice phenomena, which appear considerably later, together with shorter periods of river ice cover occurrence, are commonly noted. In the ten rivers of Lithuania, Latvia, Estonia and Belarus, during the second half of the $20^{\text {th }}$ century, the duration of ice cover shortened at a pace from about three (Daugava River) to about six (Narva River) days per ten years (Klavins, Briede \& Rodinov 2009). It is worth noting that similar trends calculated for 11 Norwegian rivers do not indicate a clear direction and are only sometimes statistically significant (Gebre \& Alfredsen 2011).

The mechanism of ice phenomena is a complex process and is determined by many factors: meteorological, hydrological, 
hydraulic and hydromorphological (Prowse 2001; Takacs et al. 2013; Marszelewski \& Pawłowski 2019). Although the decisive factors are always air and water temperatures (Yang, Pavelsky \& Allen 2020), among the other factors that play an important role, the following should also be mentioned: atmospheric precipitation (temperature and kind), riverbed parameters (depth, width), river flow speed (magnitude and nature of friction), participation of underground water alimentation, heat exchange with the environment and a number of other local factors.

In recent years, direct and indirect human impact have gained an increasing role in shaping the ice regime (Beltaos \& Prowse 2009; Takács et al. 2013). The former affects the formation of river ice through the direct impact that economic factors have on the temperature and freezing rate of water (water pollution / mineralisation); the latter indirectly influences the formation of river ice through anthropogenic changes to the morphology of river beds and river alimentation (water reservoirs, dams and weirs, channel improvement). These treatments significantly change the river longitudinal profiles and cross-sections of riverbeds, thereby affecting the speed of water inflow (Prowse 2001; Agafonova \& Frolova 2007).

The inflow of municipal sewage has a particularly important role. In the winter, it is warmer than river water (the calefaction of the river). At the same time, the pollutants contained in it significantly reduce the freezing point of water (e.g., chlorides). Simultaneously, the large amount of suspended material reduces the albedo of water and raises its temperature (Nilsson \& Malm Renöfält 2008; Takacs et al. 2013; Sheng et al. 2014; Pawłowski 2017). Moreover, the artificial controlling of water stage and river discharge play an important role in ice regime modification (Graf 2018).

The aim of the present paper is to assess the scale and direction of long-term ice regime change and river water temperature change in a medium-size Polish river (the Ner river). This is presented in the context of many years' changes in its anthropogenic alimentation, through sewage produced by the Lodz (Łódź) city agglomeration.

\section{Characteristics of the Ner river}

Changes in the ice regime of the Ner river were analysed on the basis of multiyear data from the observation point situated just above its mouth (Dabie water gauge). In the pre-industrial period, the river was a medium-size watercourse draining the eastern side of the southern Greater Poland lowlands and the western part of the Lodz Heights (Burchard et al. 2002). Its water resources were average then, and the ice regime was typical for this part of Poland. At the beginning of the $20^{\text {th }}$ century, especially in the years $1951-80$, the situation changed. The Ner became a receiver of a large amount of municipal and industrial sewage produced by the rapidly developing urban and industrial agglomeration of Lodz. This strongly affected the river's nature and regime, as well as other river features, e.g., the ice regime.

The Ner is a $3^{\text {rd }}$-order right-hand tributary of the Warta river. For almost 100 years, sewage from nearly 900,000 residents living in the Lodz agglomeration was discharged into the river (Fig. 1). The river is almost $126 \mathrm{~km}$ long and the area of the catchment up to the Dabie water gauge is $1,725.8 \mathrm{~km}^{2}$. The Ner flows into the Warta River at a distance of $448.5 \mathrm{~km}$ from its mouth to the Oder River at an altitude of about $89 \mathrm{~m}$ a.s.I. The mean river gradient is ca $0.6 \%$. The total catchment area is $1,834.3 \mathrm{~km}^{2}$ and the average height is $149 \mathrm{~m}$ a.s.l. at a denivelation of $190 \mathrm{~m}$. Agricultural areas, forests, meadows and pastures constitute the majority (about $80 \%$ ) of the Ner up to the Dabie water gauge catchment. Meanwhile, urban and industrial areas occupy over $13 \%$ of the area. In the upper part of the catchment, the percentage of urbanised area is even over $25 \%$ (Jokiel \& Bartnik 2020).
The mean long-term (1951-2017) Ner discharge at the Dabie water gauge is $10.0 \mathrm{~m}^{3} \cdot \mathrm{s}^{-1}$, and the specific runoff from the catchment is equal to $5.8 \mathrm{dm}^{3} \cdot \mathrm{s}^{-1} \cdot \mathrm{km}^{-2}$. The latter is slightly higher than the Polish mean $\left(5.5 \mathrm{dm}^{3} \cdot \mathrm{s}^{-1} \cdot \mathrm{km}^{-2}\right)$ and almost $20 \%$ higher than the mean runoff from the other catchments of the region (Jokiel 2018). The participation of the base flow in the total runoff in the Ner catchment is also unnaturally high, and averages $67 \%$. The reason for this phenomenon is a constant inflow of treated wastewater from the Lodz city agglomeration. The water is withdrawn both from local aquifers (shallow and deep, fractures and porous, occurring in Jurassic, Cretaceous, Paleogene, Neogene and Quaternary rocks) and from the neighbouring Pilica's catchment (Bartnik 2019). The wastewater is drained into the Ner river through the right-side tributaries network and through the large collector of the Combined Wastewater Treatment Plant of Lodz Agglomeration ('GOŚ ŁAM' = CWTP LA). This causes a large, unnatural increase in the inflow to the river and an apparent increase in its base flow. The inflow of wastewater is very stable over time, just like the base flow. As a consequence, the Ner river runoff regime (at Dabie water gauge) should be classified as nival and moderately well developed - type B (Wrzesiński 2016), but strongly transformed by human impact (Jokiel 2018).

The mean amount of water used in the Lodz city for municipal and industrial needs $\left(V_{u}\right)$ in the years 1951-2017 was almost equal to 75 million $\mathrm{m}^{3}$ annually. Under the previous assumption, this was approximately the average discharge of sewage, whereas after 2002 it is the discharge of treated wastewater from Lodz to the Ner river. However, the amount of these waters considerably varied over the years (Fig. 3). At the beginning of the research period (1951-54), the amount of wastewater discharged from the Lodz agglomeration did not exceed $10 \cdot 10^{6} \cdot \mathrm{m}^{-3}$ per year, and in the early 1970 s increased to over $100 \cdot 10^{6} \cdot \mathrm{m}^{-3}$ per year. The maximum was observed in 1981 , when the city of Lodz discharged over $177 \cdot 10^{6} \cdot \mathrm{m}^{-3}$ per year of raw sewage to the river. After 1985, the volume of discharged sewage decreased for many reasons that have already been mentioned. Usually, it decreased slowly and systematically (e.g., in the period 1999-2005), but in some years the registered decline was sharp - for example in 1985-86 and 1989-92. As a result, in the last decade of the entire research period, the amount of treated wastewater discharged to the Ner river stabilised at $37-50 \cdot 10^{6} \cdot \mathrm{m}^{-3}$ per year. Until 1995 , the discharged wastewater was only treated mechanically or not at all. However, after 1995 (opening of CWTP LA) full treatment (biological and chemical) began, and most of the sewage that went to the river was treated.

In the last 70 years, sewage water discharged to the Ner has changed, both quantitatively and qualitatively. This was due to various processes and phenomena associated with the increase in population of the entire Lodz agglomeration, its economic and industrial development, changes in local water management, and river water temperature changes due to the warming climate (Graf, \& Wrzesiński 2020). All of these caused long-term fluctuations and periodic trends in the quantity of sewage discharged into the river from the Lodz agglomeration, as well as similar changes in the degree of its biochemical, chemical and thermal pollution (only since 1995 has this wastewater been biologically treated in CWTP LA). As a result, not only did the fluctuations in the Ner flow and runoff regime change, but so too the river was actually a sewage channel with "biologically dead" waters in the years 1951-95. The significant transformation of the thermal and ice regime of the Ner river, especially in its middle and lower course, was an obvious consequence of this situation.

Within the last 25 years, the purity state of the Ner river has changed, and slowly improved. Less and less sewage has been flowing into it, and thus the situation has gotten better and better. Slowly, the Ner is ceasing to be a sewer and is becoming 


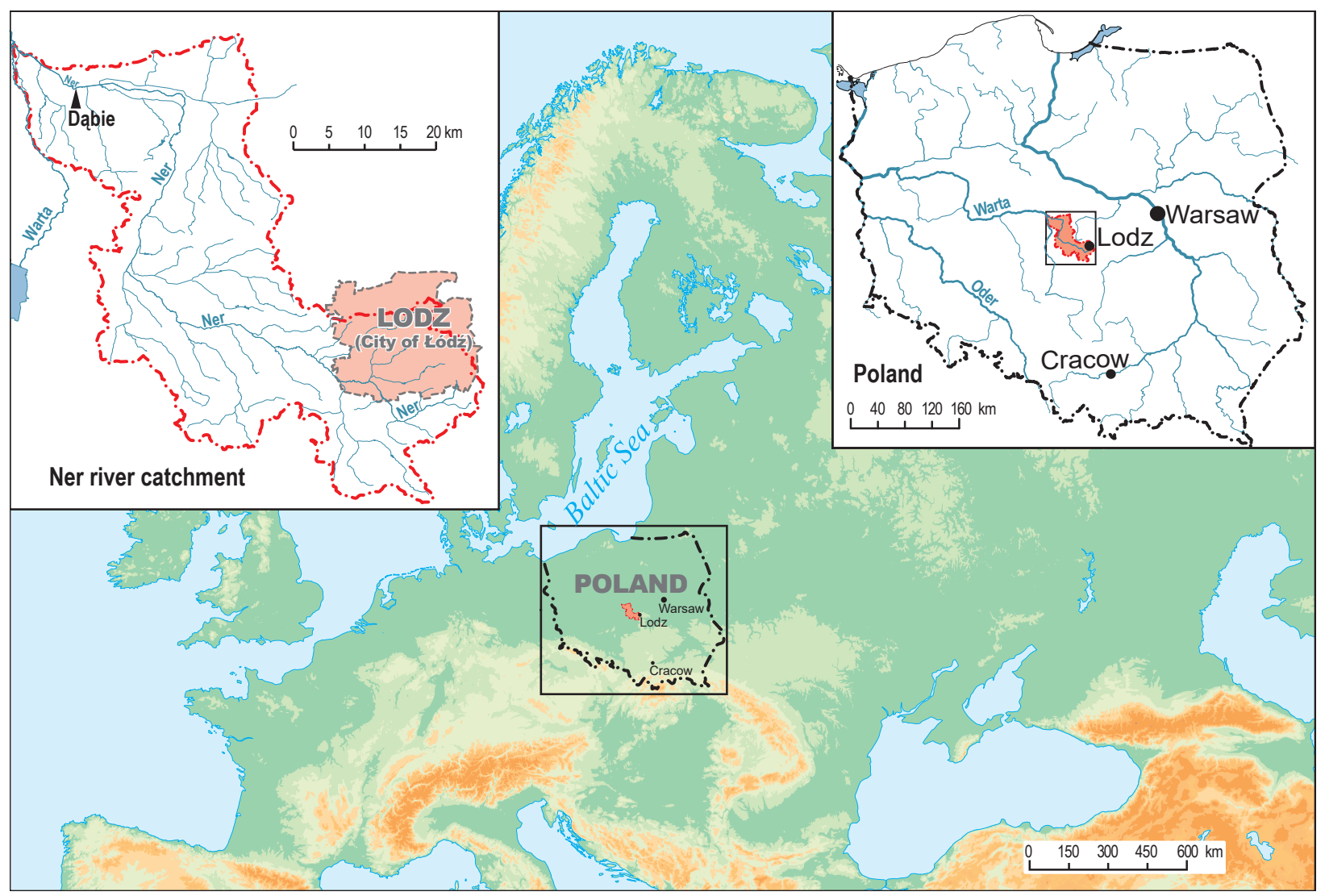

Figure 1. Location of Ner catchment area, showing Dabie (Dąbie) water gauge and the city of Lodz (Łódź) Source: own elaboration

a river again. The reason for the gradual improvement in river water quality is primarily the commissioning in 1995 of a large combined sewage treatment plant for the Lodz agglomeration (CWTP LA) and over a dozen other smaller treatment plants spread all over the river catchment.

The reduction in sewage volume and decrease in treated wastewater discharge into the Ner river was a consequence of a decrease in water demand. This was primarily caused by the collapse of the water-consuming textile industry in Lodz and its neighbouring cities (mid 1980s). Moreover, the process was a consequence of an increase in water prices for industry and the municipal economy due to the transformation to a market economy in Poland (in the 1990s). It was also the result of an end to supplying the city with large volumes of cheap but poor quality water from the Sulejowski Reservoir intakes on the Pilica river (Jokiel \& Bartnik 2020). Hence, the quantity of sewage water discharged to the Ner was reduced and its quality relatively improved at the turn of the $21^{\text {st }}$ century. This caused a slight decrease in the mean water discharge at the Dabie water gauge of about $0.5 \mathrm{~m}^{3} \cdot \mathrm{s}^{-1}$ (Jokiel 2018).

\section{Research material and methods}

Observations of various kinds of phenomena and ice forms in the Ner river at Dabie have been conducted since the water gauge was established here in 1921. They were conducted by observers of the Polish Institute of Meteorology and Water Management - National Research Institute ('IMGW-PIB' = PIMWM-NRI) service. In the pre-war years, during World War II and in the period 1945-50, the observations were incomplete (the type of phenomenon was not always noted), and the data available from these years contain numerous gaps. The series from the years 1951-2017 analysed below is complete and reliable. Its only disadvantage is that the shape of the Ner river bed has been changing so often (river control works), as has the place of observation. Nevertheless, the series of multiyear flows of the Ner river at Dabie is homogeneous (Jokiel \& Juszczak 1995).

In the years 1951-17, standard hydrometric observations and measurements at the Dabie water gauge have recorded different types of ice phenomena. The combinations of these phenomena, their forms, the dates of appearance and disappearance of ice sheets, and other ice forms were documented. Ice thickness has occasionally been measured. To standardise the research presented below and simplify the diagrams and calculations, the series of appearances and disappearances of ice cover and all ice phenomena were analysed (Fig. 2). The start dates and end dates of all ice phenomena occurrences, as well as the start dates and end dates of ice cover appearances, have been analysed together with their duration in the period 1951-2017.

Data on the volume of wastewater discharged from the Lodz agglomeration to the sewage system and then to the Ner river are very fragmentary and imprecise, and therefore cannot be analysed for the long-term period. Information on the amount of water used in Lodz in 1951-2017 is available ( $V_{u}$; Fig. 3). Despite the fact that it can be found in various sources, it is difficult to verify. The data have multiple gaps and are therefore very inaccurate. Nevertheless, they can provide some approximation to the amount of wastewater discharged into the Ner River during this period. It needs to be highlighted that the Ner river 


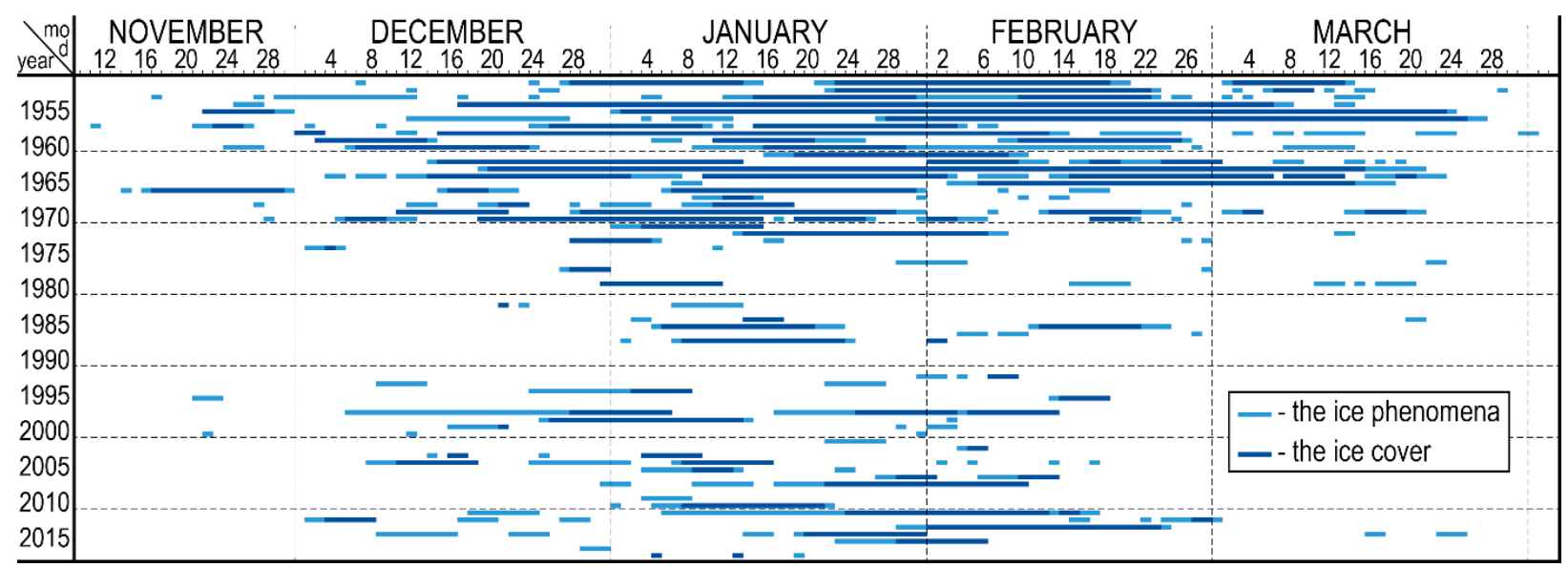

Figure 2. Days of river ice phenomena (light blue) and river ice cover (dark blue) on the Ner river at Dabie water gauge, 1951-2017 Source: own elaboration (developed using data from IMWM-NRI)

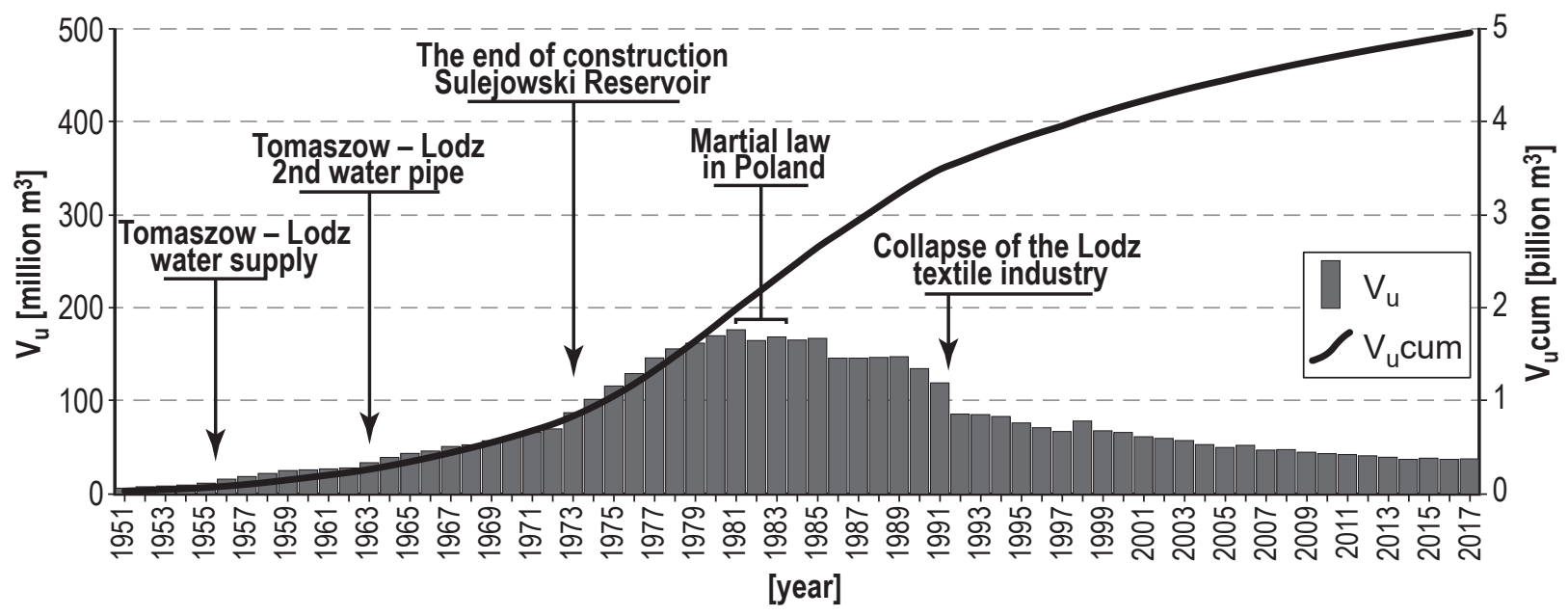

Figure 3. Annual water usage in Lodz city agglomeration $\left(V_{u}\right)$ and its cumulated quantity (V $V_{u}$ cum), 1951-2017

Source: own elaboration (developed using archival materials of the City of Lodz Office, Statistical Yearbooks of the City of Lodz, CSO Local Data Bank, and Environmental Protection and Water Management Reports)

has been collecting the vast majority of sewage flowing from the entire Lodz agglomeration from the moment the city was created (Jokiel \& Bartnik 2020). The existing gaps in data on the volume of annual water consumption of the Lodz agglomeration (occurring in 1974-80 and 1993-98) have been supplemented using regression equations for the following relationship between the variables: the amount of water consumed and the amount of water supplied to homes; and the amount of water consumed and the volume of sewage discharged from the Lodz agglomeration. The determination coefficients of these equations are, respectively: 0.99 and 0.94 , and the formulas are statistically significant at $1 \%$ (Mann-Kendall test). The changes in the amount of water that was consumed yearly by the Lodz agglomeration in the years 1951-2017 are presented in Fig. 3.

At the first stage of the investigation, the specified terms of appearance and disappearance of ice phenomena and ice cover were determined for each year of the multiyear period. On their basis, the duration of ice phenomena and ice cover on the Ner river was calculated for specific years. Further calculations of the long-term changes in the occurrence of ice phenomena on the river were made using several basic statistical methods and procedures (mean, standard deviation, coefficient of variation, etc.). The existence of trends in the series was examined by the non-parametric Mann-Kendall statistical test (Mann 1945; Kendall 1975) mentioned above. Nowadays, this method is often used to detect the existence of trends in various hydrological time series. Examples of works in which this test was also used include: Steele et al. 1974; Hirsch et al. 1982; Hirsch \& Slack 1984; Crawford et al. 1983; van Belle \& Hughes 1984; Cailas et al. 1986; Hipel et al. 1988; Taylor \& Loftis 1989; Demaree \& Nicolis 1990; Zetterqvist 1991; Yu et al. 1993; Chiew \& McMahon 1993; Burn \& Hag Elnur 2002; Lettenmaier et al. 1994; Gan 1998; Lins \& Slack 1999; Douglas et al. 2000; Hamilton et al. 2001; Yue \& Hashino 2003; Yue \& Wang 2004. In the next stage, the directions and strength of linear trends occurring in the series of dates of appearance and disappearance of phenomena and ice cover were determined (using least squares method) and the coefficients of determination $\left(R^{2}\right)$ of their equations were calculated (Wright 1921; Sen \& Srivastava 1990).

The double mass method was used to assess the impact of water consumption and relationships between the number 

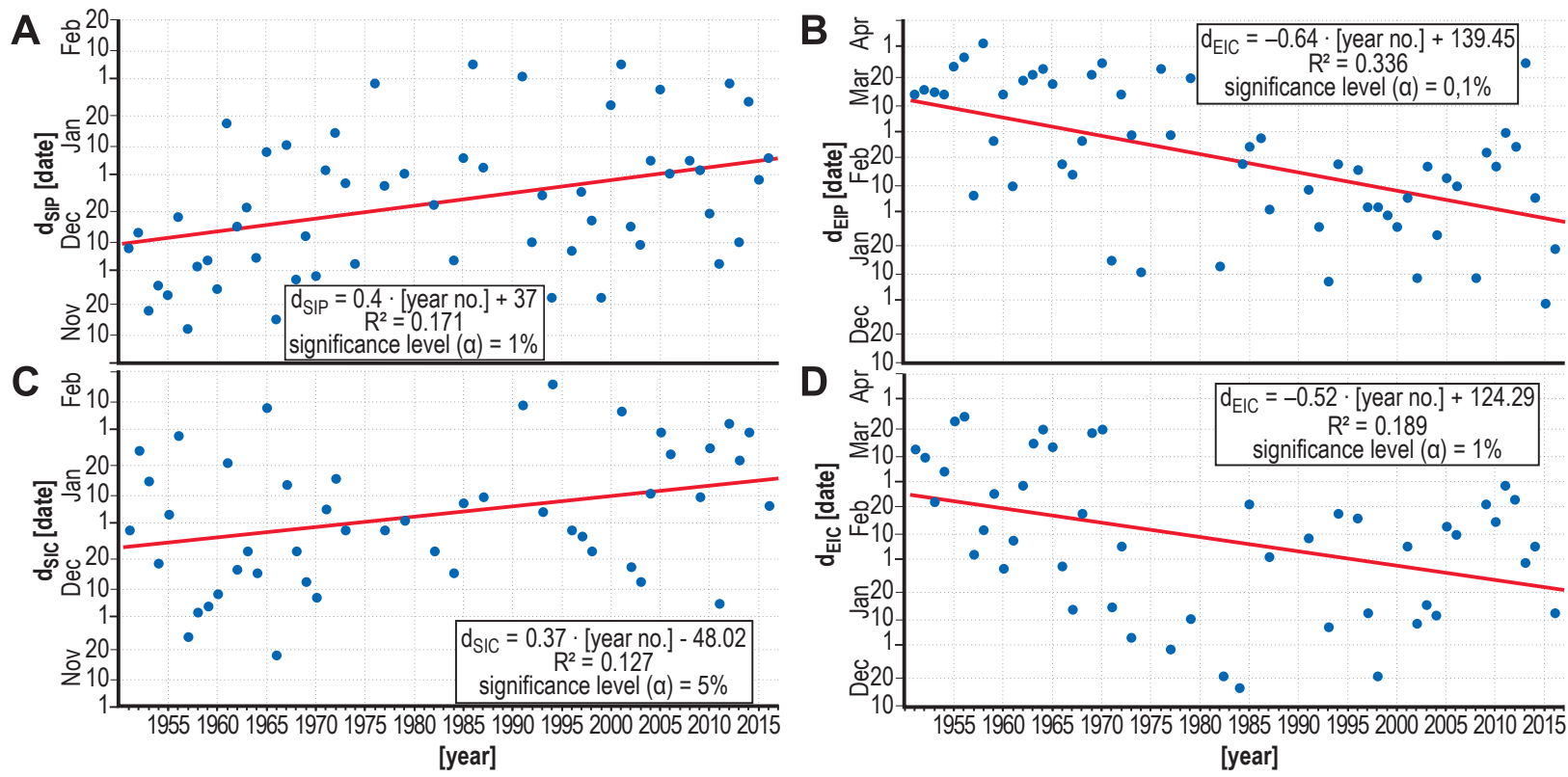

Figure 4. Variability of start $\left(d_{S I P}-A\right)$ and end $\left(d_{E I P}-B\right)$ dates of ice phenomena occurrence, as well as start $\left(d_{S I C}-C\right)$ and end $\left(d_{E I C}\right.$ - D) dates of ice cover appearance on the Ner river at Dabie water gauge, 1951-2017. Red lines show trends. Trend equations given in boxes; $R^{2}$ - coefficients of determination; [year no.] - consecutive number of year from beginning of data series (1951 is no. 1); $\alpha$ - significance level of trend equations; Mann-Kendall test was used.

Source: own elaboration

of days with phenomena and ice cover on the Ner river and water consumption in the Lodz city agglomeration. This is a recognised method of detecting heterogeneity in data series. The double-mass curve is based on the concept that a graph of the cumulative data of one variable versus the cumulative data of another is a straight line, as long as the relation between the variables is a fixed ratio (Searcy \& Hardison 1960; Linsley et al. 1975). When an inconsistency is noted, further investigation into its cause is warranted. Major breaks in slope indicate that the data is nonhomogeneous.

\section{Results and discussion} Ice regime changes

Analysing the occurrence of ice phenomena in the Ner river, it is easy to notice some of the most important features and changes in the ice phenomena regime within the research period (Fig. 2). The annual appearance of various ice phenomena and ice cover in fact ended in 1972. It was also accompanied by the disappearance of full ice cycles. Starting around this time, for the next 20 years, ice phenomena, and especially ice cover, appeared on the river rarely and very irregularly (on average every other year). The incidence of various ice forms on the Ner river increased again after 1990, especially in the first decade of the $21^{\text {st }}$ century. They began to appear on average twice every three years. The reason was the decrease in the amount of wastewater discharged into the Ner river, and the improvement in the purity of the river water. This slowed the process of water temperature increase, which was then even halted by the influence of the cold winters of the late $20^{\text {th }}$ and early $21^{\text {st }}$ centuries. In the years 1990-2015, the temperature of winters in Poland decreased - a negative local trend (Marsz \& Styczyńska 2018).

The earliest dates recorded for the appearance of ice phenomena and ice cover were in 1957 and 1965. They were: November 11 (ice phenomena) and November 23 (ice cover), respectively. Ice phenomena and ice cover usually appeared in
November or in the first half of December until the end of the 1960s. Later, this date gradually moved later - to the middle of winter.

The latest beginnings of ice phenomena and ice cover were noted for February $4^{\text {th }}$ (in 1986 and 2001) and February 14 $4^{\text {th }}$, 1994 , respectively. Both forms appeared only for a short time less than 10 days. The large variation in the date of occurrence of ice phenomena and ice cover, as well as the significant upward trends (significance levels: $\alpha=0.1 \% ; 1 \%$ and $5 \%$ ), in the multiyear period also indicate a gradual shift of both dates towards the middle of winter (Fig. 4A \& 4C). Mean rates of shift in dates of occurrence of both forms of ice to the middle of winter were similar in this multiannual period and were equal to 4 and less than 4 days per decade, respectively.

Moreover, the dates of disappearance of ice phenomena and ice cover have been very diverse for many years, similar to the dates of their occurrence (Fig. 4B \& 4D). In the mid1950s, phenomena and ice cover disappeared relatively late, even at the end of March. However, in the mid-1980s the ice cover was already disappearing in December or in January. The calculated trends, indicating the gradual shift in both dates towards the middle of the winter are in this case even stronger, and their statistical significance is better than obtained for the dates of their appearance (compared with Fig. 4A \& 4C). The mean rates of shift in dates of disappearance of ice phenomena and ice cover were six and five days per decade, respectively. It should be noted that the linear nature of the trend function is questionable here, because at the beginning of the 1980s there appeared a peculiar discontinuity in the series. Until then, both disappearance dates had varied significantly. Then they quickly moved back to stabilise and oscillate around the local mean.

Another obvious consequence of large changes and fluctuations in the date of occurrence of ice phenomena and ice cover is a large variability in the number of days with ice phenomena and ice cover (Fig. 5). The number of days on which 


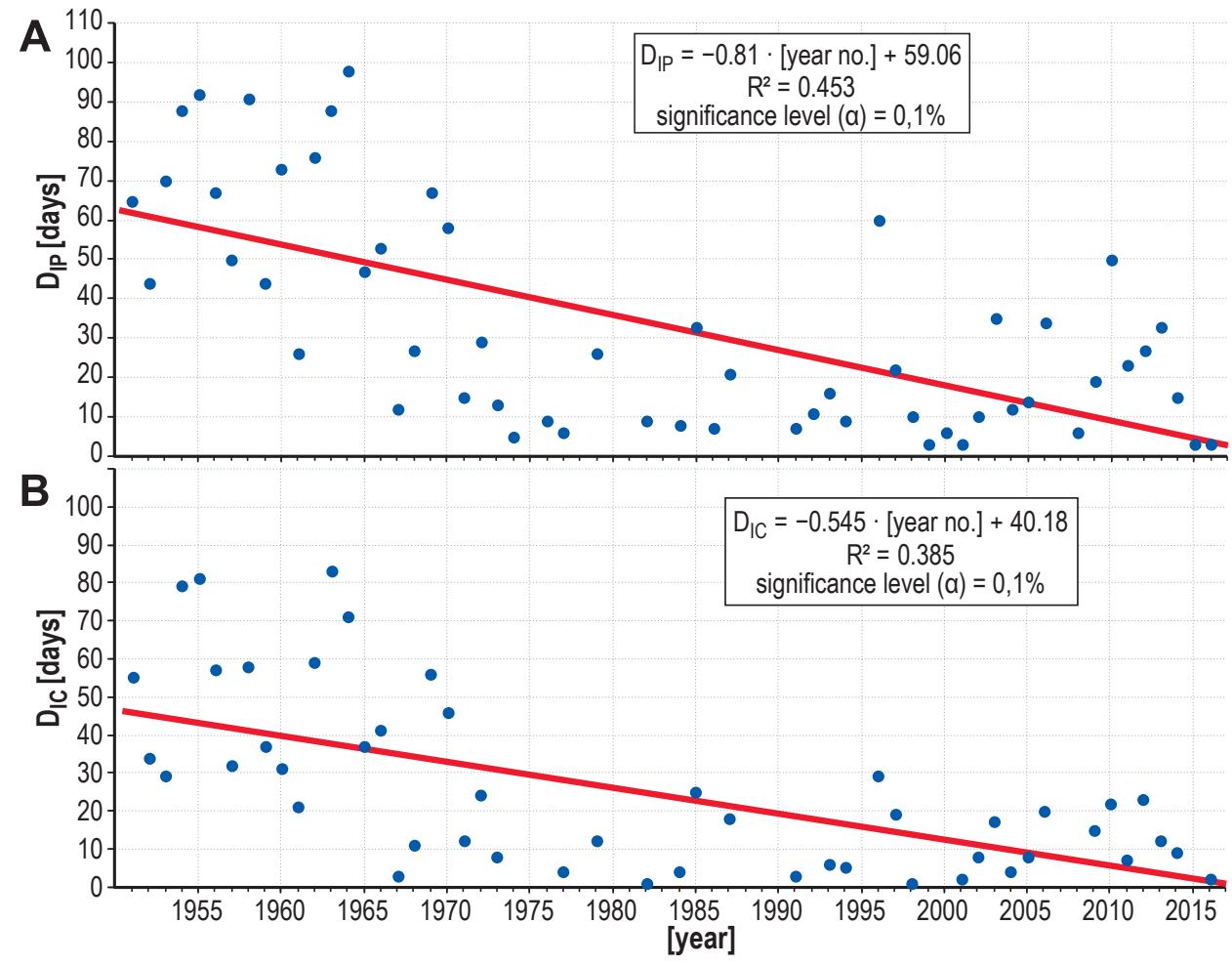

Figure 5. Variability of duration of ice phenomena $\left(D_{I P}-A\right)$ and ice cover $\left(D_{I C}-B\right)$ on the Ner river at Dabie water gauge, $1951-$ 2017. Red lines show trends. Trend equations given in boxes; $R^{2}-$ coefficients of determination; [year no.] - consecutive number of year from beginning of data series (1951 is no. 1); $\alpha$ - significance level of trend equations; Mann-Kendall test was used. Source: own elaboration

various forms of ice were observed on the Ner river ranged from 99 days in 1964 down to five days (many times). During 11 winters in the long-term period (mainly in the years 1970-90), no ice forms were found in the river (Fig. 2). The duration of ice cover also varied: from 82 days in 1963 to one day in 1982 and 1998. During 18 winters, ice cover on the river did not occur at all (mainly in the 1970s and in the 1980s). A statistically significant linear trend (level of significance: $\alpha=0.1 \%$ ) indicates that the duration of ice phenomena in the Ner river decreased on average by eight days per decade (Fig. 5A). A much slower rate of change was calculated for the neighbouring Prosna river in the Boguslaw cross-section (Ptak \& Nowak 2017). They were estimated at 5.6 days per decade (Fig. 5B).

The obtained linear trends do not reflect the observed changes in the duration of ice phenomena and ice cover quite properly. The arrangement of points indicates the existence of heterogeneity in the series $D_{\mathbb{I P}}$ and the occurrence of discontinuities in it in the early 1980s (Fig. 5A). This discontinuity is manifested in relation to both partial means and local dispersion. In the years 1951-80, the downward trend in the number of days with ice phenomena was clear, and the dispersion of the phenomenon was very large. The average rate of decline exceeded 15 days per decade. However, this trend collapsed in the early 1980s and for the next decades $D_{\mid \mathrm{P}}$ in the Ner river oscillated around 20 , while the series had relatively low variability.

Similar regularities are observed regarding the changes in the duration of ice cover on the Ner river (Fig. 5B). The linear trend in the whole series is also clear and statistically significant $(\alpha=0.1 \%)$. According to this trend, the number of days with ice cover decreased on average over five years at a rate of five days per decade. However, also in this case, at the beginning of the 1980s a breakthrough was observed. Subsequently, the strong downward trend recorded in the first half of the period disappeared and the dispersion visibly decreased. After this collapse, the annual number of days with ice cover began to oscillate around ten, and its diversity in individual years also decreased.

The ice regime of the Ner river has changed fundamentally over the past 70 years. The frequency of occurrence of ice phenomena and ice cover on the river has significantly decreased. The dates of their beginning and disappearance changed and as a consequence, the duration of these phenomena has been reduced by almost half. Complete ice cycles are rare today in the Ner river, and frazil, and freeze-up ice jams no longer occur despite the riverbed predisposition. Similar trends were noted for many other Polish rivers, both large and small. Global warming and the associated rise in river temperature (especially in winter) are considered to be the main cause of this phenomenon (Marszelewski 2010; Graf 2015, 2018; Pawłowski 2017; Ptak \& Nowak 2017). It seems, however, that in the Ner River, long-term changes in the duration of ice phenomena and ice cover were not continuous and systematic, which is typical for changes caused by global warming. Emerging discontinuities and sudden changes indicate that another factor also played an important role - local human impact.

\section{Determinants of changes in ice regime}

In the last half-century, the average temperature of European rivers has increased by a value similar to that recorded for the average increase in air temperature: $1.0-1.5{ }^{\circ} \mathrm{C}$ (EEA 2012). The upward trend is visible and quite systematic and its cause is obvious - warming, especially in the cool half-year. In the aspect of observed long-term fluctuations in river water temperature, 
some researchers indicate that the change (oscillation) in atmospheric circulation over Europe (e.g., NAO, AO and others) also plays an important role. It can cause additional alterations in the direction and scale of changes in river water temperature and ice phenomena in the world and in Europe. However, the correlations and spatial relationships occurring here are not explicit and the connections obtained are not always statistically significant (Bonsal et al. 2005; Klavins, Briede \& Rodinov 2009; Gebre \& Alfredsen 2011; Graf \& Wrzesiński 2019).

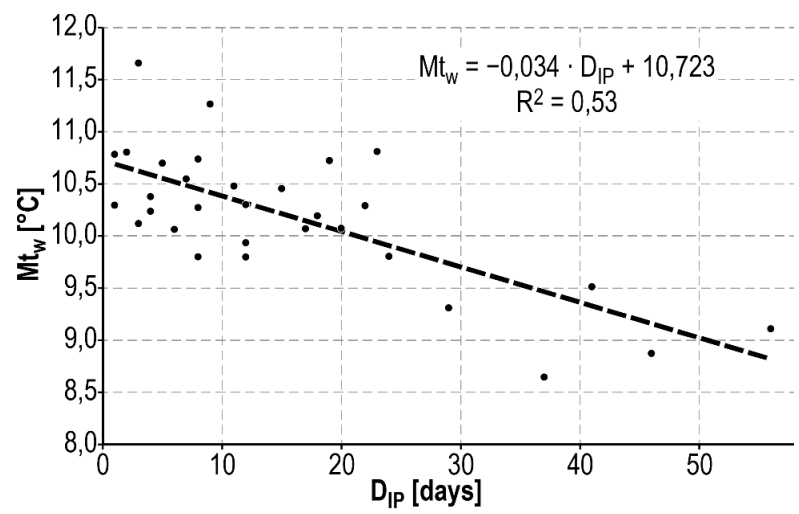

Figure 6. Correlation between duration of ice phenomena on the Ner river $\left(D_{I P}\right)$ and annual mean water temperature $\left(M t_{w}\right)$ in particular years within 1965-2014

$R^{2}$ - coefficient of determination

Source: Jokiel \& Bartnik 2020
The increase in water temperature of Polish rivers caused by global warming is already a well-documented fact, especially in lowland rivers. Many researchers emphasise that this increase is sometimes locally reinforced by human impact, and in particular by the transformation of local water management (Marszelewski 2010; Łaszewski 2014; Graf 2015, 2019; Marszelewski \& Pius 2016; Pawłowski 2017; Ptak \& Nowak 2017; Jokiel \& Bartnik 2020). It is estimated that anthropogenic factors can further increase mean annual and seasonal river water temperatures by up to several degrees. The water temperature of the river rises fastest in the cold halfyear. Its visible effects are large changes in the frequency and duration of ice phenomena and ice cover on rivers (Graf 2015, 2019; Łaszewski 2018).

The mean annual water temperature of the Ner river in the years 1965-2014 increased at a rate of $0.23{ }^{\circ} \mathrm{C}$ per decade, but its increase was not even. In the years $1965-95$ it was very fast $\left(0.8{ }^{\circ} \mathrm{C}\right.$ per decade), and later it fell to $0.2{ }^{\circ} \mathrm{C}$ per decade (Jokiel \& Bartnik 2020). Jokiel and Bartnik also point to a regression relationship between the Ner river water temperature and the duration of ice phenomena at the Dabie water gauge (Fig. 6). The obtained regression equation indicates that the $1{ }^{\circ} \mathrm{C}$ increase in mean annual water temperature of the Ner river reduced the number of days with ice phenomena per year by about 30 .

The long-term changes in the date of appearance and disappearance of ice phenomena and ice cover on the Ner river, as well as the visible genetic non-homogeneity of time series of ice phenomena and ice cover, are shown in Fig. 4 and Fig. 5, respectively. They do not provide an unequivocal answer to the questions of i) Do the observed changes in the ice regime of the Ner river result only from an increase in river water temperature caused by global warming? or ii) Are the discontinuous rise in temperature and the changes in the ice regime anthropogenic and

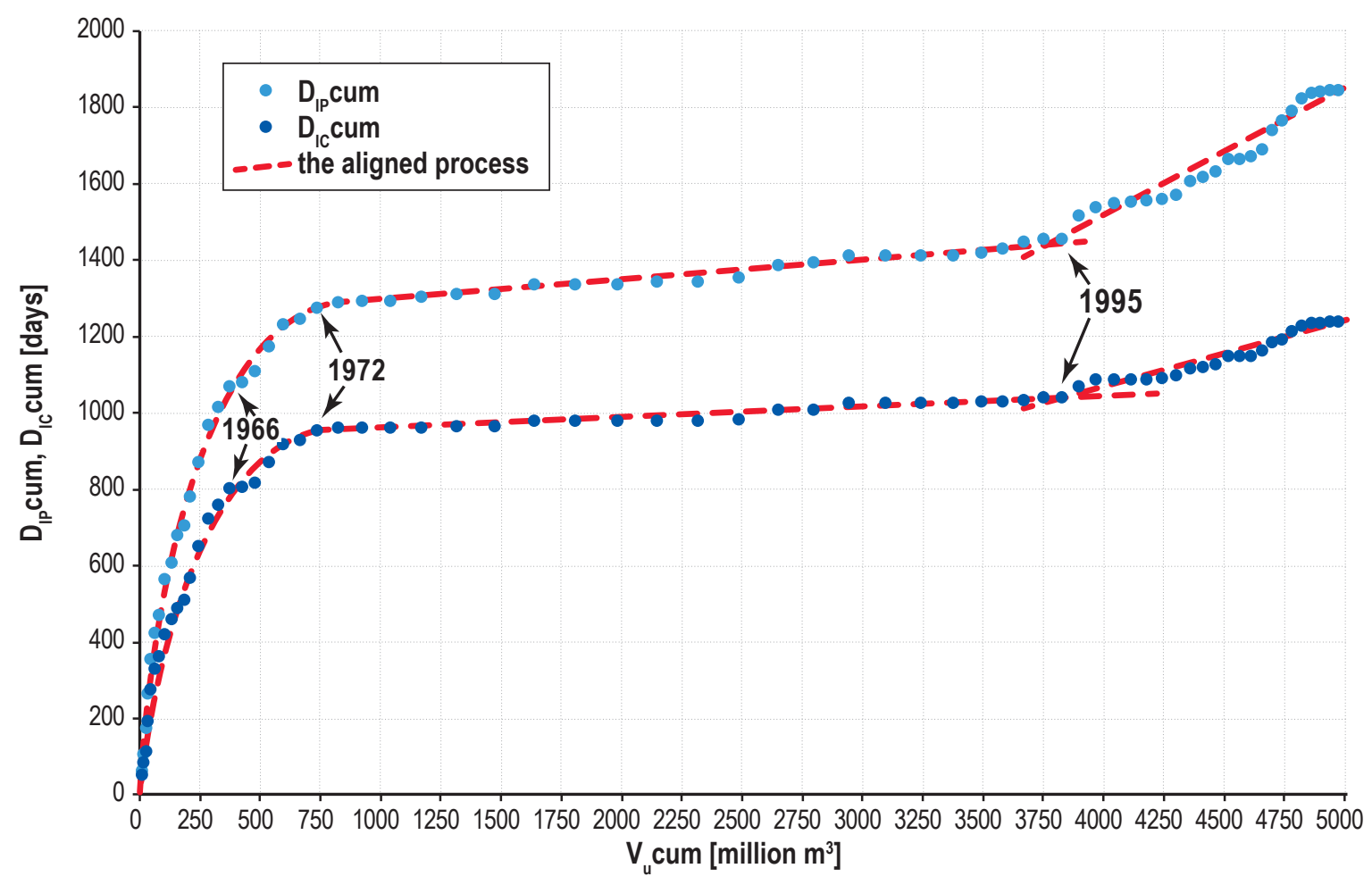

Figure 7. Double-mass curves of cumulated duration of ice phenomena $\left(D_{1 P}\right.$ cum) and cumulated duration of ice cover $\left(D_{1 C} c u m\right)$ on the Ner river at Dabie water gauge versus cumulated volume of water uptake by Lodz city agglomeration $\left(V_{u}\right.$ cum $), 1951-2017$. Red lines are aligned cumulations; arrows indicate years of significant disruption of homogeneity.

Source: own elaboration 
the result of the nature of wastewater discharged into the river? The answer to these questions can be obtained by analysing the shape of the double-mass cumulated curves set for the annual water consumption in the city of $\operatorname{Lodz}\left(\mathrm{V}_{\mathrm{u}}\right)$ and the annual duration of ice phenomena and ice cover $\left(D_{1 \mathrm{P}} ; D_{1 \mathrm{C}}\right)-$ Fig. 7 .

The shapes of these curves indicate that the changes during the occurrence of ice phenomena in the Ner river were very diverse during the period. There were at least three rapid changes resulting from an increase or decrease in water consumption in the city of Lodz, which caused similar changes in the amount of sewage discharged into the river. Until 1966, the number of days with ice phenomena and ice cover $\left(D_{\mid P}\right.$; $D_{I C}$ ) registered annually increased sharply, and was relatively constant when described as a percentage of the amount of water consumed in the city $\left(\mathrm{V}_{\mathrm{u}}\right)$. After that year, the relationship between the two variables changed slightly. The number of days during which ice phenomena or ice cover were recorded in the Ner river began to grow more slowly - ice phenomena began to disappear from the river. The fairly sharp decline in $D_{I P}$ and $D_{I C}$ observed in this period compared to the $V_{u}$ was the obvious result of the large increase in water consumption in the Lodz city. It also resulted in a visible increase in the amount of relatively warm wastewater being discharged into the river. Untreated industrial and municipal wastewater discharged today to the CWTP LA treatment plant and previously discharged directly to rivers had and has a relatively stable temperature, although, during negative air temperatures (in winter) and after thaws, it is much higher (by about $5{ }^{\circ} \mathrm{C}$ ) than the temperature of river waters (Brzezińska 2011; Briciu et al. 2020). Such a consumption increase was possible due to the commissioning of a second pipeline supplying water to Lodz from the Pilica river (water pumping began at the end of 1963). Another commissioning (in 1973) of the Sulejowski Reservoir and a pipeline supplying large amounts of water from the Pilica to Lodz had a much greater impact on the relationship between the studied variables. In the early 1970 s, ice phenomena on the Ner river disappeared, and this condition persisted for the following 20-25 years.

The situation clearly changed in the early 1990 s. The collapse of the textile industry in the city and the entire agglomeration (1990-93) and the systematic increase in water prices for users caused a sharp decrease in its consumption and, consequently, a significant reduction in the amount of waste water discharged into the Ner river (treated since 1995). In winter, the river water temperature dropped again, as did its pollution. Accordingly, the relation between the number of days with ice phenomena and ice cover with the sewage volume changed again, but in the opposite direction. The shape of the double-mass curve after 1995 clearly indicates that the process of decreasing the annual number of days with ice phenomena stopped and the relationship between $V_{u}$ and $D_{I P}$ and $D_{I C}$ was preserved at a relatively stable level. Therefore, reducing the amount of sewage, improving the quality of its treatment, and then stabilising both variables at a relatively constant level led to a more frequent occurrence of ice phenomena and ice cover on the river. Currently, the frequency of their appearance and duration in the Ner river have stabilised at a new level, though much lower than in the 1950s (see Fig. 2).

\section{Conclusions}

In the years 1951-2017, the ice phenomena on the Ner river changed significantly and were very diverse. Over the years, ice cover and other ice phenomena have become briefer. They started occurring later and disappeared earlier. The duration and frequency of these phenomena also decreased. However, these changes have not been a continuous process for many years, but they were very diverse in pace, scale and direction. The reasons for the changes in the Ner river ice regime were not only changes in river water temperature caused by global warming (the constant direction and pace of change), but also additional fluctuations in this temperature determined by changes in the quantity and quality of wastewater discharged into the river from the Lodz city agglomeration. The observed fluctuations in the duration and the frequency of ice phenomena allowed four periods to be distinguished in the examined period that are characterised by differing paces and directions of changes in the river ice regime (compare Fig. 2 \& Fig. 7):

1. 1951-65: the phase of slow disappearance of ice phenomena in the river caused by a systematic but small increase in water temperature.

2. 1966-72: the phase of rapid disappearance of ice phenomena caused mainly by the rapid increase in river water temperature as a result of the discharge of increased amounts of untreated sewage.

3. 1973-95: the phase with very low frequency and duration of ice phenomena caused and maintained by a slow increase in water temperature with a large discharge of untreated sewage.

4. 1996-2017: the phase of growth and stabilisation of the duration and frequency of the ice phenomena caused by a decrease in quantity and improvement in quality of treated wastewater discharged into the river.

The observed changes and fluctuations in the frequency and duration of ice phenomena in the Ner river are a good example illustrating the overlapping of changes caused by a local anthropogenic factor (here, sewage discharge) and the relatively time-stable changes caused by a regional factor (increase in water temperature) caused by global warming.

\section{Funding}

The article was prepared as a part of research on water circulation in conditions of strong human impact on the example of the Ner river. They were financed from the statutory research of the Hydrology and Water Management Department of the University of Lodz.

\section{ORCID}

Adam Bartnik (D) https://orcid.org/0000-0003-3726-5427

Paweł Jokiel (1D https://orcid.org/0000-0002-6771-2294

\section{References}

Agafonova, SA \& Frolova, NL 2007, 'Specific features of ice regime in rivers of the Northern Dvina Basin', Water Resources, vol. 34, pp. 123-131.

Bartnik, A 2019, 'Main features of the geographical environment of Łódź' in Atlas Historyczny Miasta Łodzi dla Nauki, Edukacji, Kultury, Gospodarki i Społeczeństwa, ['Historical Atlas of the City of Łódź for Science, Education, Culture, Economy and Society'], ed. M Koter, Łódzkie Towarzystwo Naukowe, Łódź.
Beltaos, S \& Prowse, T 2009, 'River-ice hydrology in a shrinking cryosphere', Hydrological Processes, vol. 23, no. 1, pp. 122-144.

Bonsall, P, Prowse, TD, Duguay, CR \& Lacroix, MP 2005, 'Impacts of large-scale teleconnections on river-ice duration over Canada', CGU HS Committee on River Ice Processes and the Environment, 13th Workshop on the Hydraulics of Ice Covered Rivers, Hanover, NH, September 15-16, 2005. 
Briciu, A-E, Mihăilă, D, Graur, A, Oprea, DI, Prisăcariu, A \& Bistricean, PI 2020, 'Changes in the water temperature of rivers impactedby the urban heat island: Case study of suceava city', Water, vol. 12 , no. 5, pp. 1-24.

Brzezińska, A 2011, 'Zmiany temperatury ścieków ogólnospławnych na podstawie pomiarów on-line', ['Variability of combined wastewater temperature on the basis of on-line measurements'], Inżynieria Ekologiczna, vol. 26 , pp. 290-302.

Burchard, J, Nalewajko, J, Budzyńska, M, Czubla, P, Hereźniak, J, Maksymiuk, Z, Markowski, J, PaturalskaNowak, E \& Skrzypski, J 2002, 'Sheet I: Łódź's location within the natural structures of Poland and the region' in 'The Łódź Atlas', ed. S Liszewski, Łódzkie Towarzystwo Naukowe, Łódź. Available from: <http://mapa.lodz.pl/mapa/atlas/eng/en-01R.pdf>. [4 April 2020].

Burn, DH \& Hag Elnur, MA 2002, 'Detection of hydrological trends and variability', 'Journal of Hydrology', vol. 255, no. 1-4, pp. 107-122.

Cailas, MD, Cavadias, G \& Gehr, R 1986, 'Application of a nonparametric approach for monitoring and detecting trends in water quality data of the St. Lawrence River', Water Pollution Research Journal of Canada, vol. 21, no. 2, pp. 153-167.

Chiew, FHS \& McMahon TA 1993, 'Detection of trend or change in annual flow of Australian rivers', International Journal of Climatology, vol. 13, pp. 643-653.

Crawford, CG, Slack, JR \& Hirsch, RM 1983, 'Nonparametric tests for trend in water quality data using the statistical analysis system', Open Report, No. 83-550, U.S. Geological Survey, USA, pp. 1-102.

Demaree, GR \& Nicolis, C 1990, 'Onset of Sahelian drought viewed as a fluctuation-induced transition', Quarterly Journal of the Royal Meteorological Society, vol. 116, pp. 221-238.

Douglas, EM, Vogel, RM \& Kroll, CN 2000, 'Trends in floods and low flows in the United States: impact of spatial correlation', Journal of Hydrology, vol. 240, pp. 90-105.

EEA, 2012, 'Climate change, impacts and vulnerability in Europe 2012. An indicator-based report', EEA Report, No 12/2012, EEA, 21 November 2012, Copenhagen, Denmark. Available from: <https://www.eea.europa.eu/publications/climateimpacts-and-vulnerability-2012>. [4 April 2020].

Gan, TY 1998, 'Hydroclimatic trends and possible climatic warming in the Canadian Prairies', Water Resource Research, vol. 34, no. 11, pp. 3009-3015.

Gebre, SB \& Alfredsen, KT 2011, 'Investigation of river ice regimes in some Norwegian water courses' in Proceedings of the 16th Workshop on the Hydraulics of Ice Covered Rivers Winnipeg, MB, Canada, 18-22 September 2011; CGU HS Committee on River Ice Processes and the Environment: Winnipeg, MB, Canada, pp. 1-20.

Gołek, J 1961, Termika rzek Polskich [Thermal conditions of Polish rivers], Wydawnictwo Komunikacji i Łączności, Warszawa.

Graf, R \& Wrzesiński, D 2019, 'Relationship between Water Temperature of Polish Rivers and Large-Scale Atmospheric Circulation', Water, vol. 11, no. 8, pp. 2-30.

Graf, R 2015, 'Zmiany termiki wód Warty w profilu łączącym pradolinny i przełomowy odcinek doliny (Nowa Wieś Podgórna - Śrem - Poznań)' ['Variations of the thermal conditions of Warta in the profile connecting the urstromtal and gorge stations of the valley (Nowa Wieś Podgórna - Śrem - Poznań) '] in Nowe metody i rozwiązania w hydrologii i gospodarce wodnej ['New methods and solutions in hydrology and water management'], eds $D$ Absalon, $M$
Matysik \& M Ruman, Monografie Komisji Hydrologiczne PTG. vol. 3, Katowice, pp. 177-194.

Graf, R 2018, 'Uwarunkowania termiczne tworzenia się i utrzymywania pokrywy lodowej na Noteci' ['Thermal conditions of the formation and persistence of ice cover on the River Noteć'], Prace Geograficzne, vol. 153, no. 153, pp. 25-47.

Graf, R \& Wrzesiński, D, 2020, 'Detecting patterns of changes in river water temperature in Poland', Water, vol. 12, no. 5. 1-20.

Hamilton, JP, Whitelaw, GS \& Fenech, A 2001, 'Mean annual temperature and annual precipitation trends at Canadian biosphere reserves', Environmental Monitoring and Assessment, vol. 67, pp. 239-275.

Hipel, KW, McLeod, Al \& Weiler, RR 1988, 'Data analysis of water quality time series in Lake Erie', Water Resource Bulletin, vol. 24, no. 3, pp. 533-544.

Hirsch, RM \& Slack, JR 1984, 'Non-parametric trend test for seasonal data with serial dependence', Water Resource Research, vol. 20, no. 6, pp. 727-732.

Hirsch, RM., Slack, JR \& Smith, RA 1982, 'Techniques of trend analysis for monthly water quality data', Water Resource Research, vol. 18, no. 1, pp. 107-121.

Jokiel, P \& Bartnik, A 2020, Ner. Monografia hydrologiczna niekochanej rzeki [Ner. The hydrologic monograph of unloved river], Wydawnictwa Uniwersytetu Łódzkiego, Łódź.

Jokiel, P 2018, 'Wpływ antropopresji na zmiany przepływu Neru w przekroju Dąbie' ['Human impact on the Ner flow changes within Dabie water-gauge cross section'], Prace $i$ Studia Geograficzne, vol. 63, no. 3, pp. 103-118.

Jokiel, P \& Juszczak, K, 1995, 'Jednorodność wieloletnich serii średnich i średnich niskich przepływów rzek Polski środkowej', ['Homogeneity of the multiyear series of mean and mean of the low flows of rivers in central Poland'], Wiadomości IMGW, vol. 1, Warsaw.

Kendall, MG 1975, Rank Correlation Methods, Griffin, London.

Klavins, M, Briede, A \& Rodinov, V 2009, 'Long term changes in ice and discharge regime of rivers in the Baltic region in relation to climatic variability', Climatic Change, vol. 95, pp. 485-498.

Lettenmaier, DP, Wood, EF \& Wallis, JR 1994, 'Hydroclimatological trends in the continental United States, 194888', Journal of Climate, vol. 7, pp. 586-607.

Lins, HF \& Slack, JR 1999, 'Streamflow trends in the United States', Geophysical Research Letters, vol. 26, no. 2, pp. 227-230.

Linsley, RK, Kohler, MA\& Paulhus, JLH 1975, 'Applied Hydrology', McGraw-Hill, New Delhi.

Magnuson, JJ, Robertson, DM, Benson, BJ, Wynne, RH, Livingstone, DM, Arai, T, Assel, RA, Barry, RG, Card, V, Kuusisto, E, Granin, NG, Prowse, TD, Stewart, TD \& Vuglinski, VS 2000, 'Historical trends in lake and river ice cover in the Northern hemisphere', Science, vol. 289, pp. 1743-1746.

Mann, HB 1945, 'Nonparametric tests against trend', 'Econometrica', vol. 13, pp. 245-259.

Marsz, AA \& Styczyńska A, 2018, 'Przebieg temperatury zim na obszarze Polski w latach 1720-2015' ['Course of winter temperatures in Poland in the years 1720-2015'], Prace Geograficzne, vol. 155, pp. 85-138.

Marszelewski, W \& Pawłowski, W 2019, 'Long-Term Changes in the Course of Ice Phenomena on the Oder River along the Polish-German Border', Water Resources Management: An International Journal, Published for the European Water Resources Association (EWRA), vol. 33, no. 15, pp. 51075120 .

Marszelewski, W 2010, 'Wpływ zmian klimatycznych na temperaturę wód powierzchniowych w północnej Polsce' 
['Impact of the climate change on the surface water temperature in the northern Poland'], Monografie Komitetu Inżynierii Środowiska PAN, vol. 69, no. 2, pp. 341-349.

Nilsson, C \& Malm Renöfält, B 2008, 'Linking flow regime and water quality in rivers: a challenge to adaptive catchment management', Ecology and Society, vol. 13, no. 2, Available from: <http://www.ecologyandsociety.org>. [4 April 2020]

Pawłowski, B 2017, Przebieg zjawisk lodowych dolnej Wisły w latach 1960-2014 [Course of ice phenomena on the Lower Vistula River in 1960-2014], Wydawnictwo Uniwersytetu im. Mikołaja Kopernika, Toruń.

Pawłowski, B, Gorączko, M \& Szczerbińska, A 2017, 'Zjawiska lodowe w rzekach Polski' ['Ice phenomena in Polish rivers'] in Hydrologia Polski [Hydrology of Poland], eds P Jokiel, W Marszelewski \& J Pociask-Karteczka, Wydawnictwo Naukowe PWN, Warszawa, pp. 195-200.

Prowse, TD 2001, 'River-ice ecology. II: biological aspects', Journal of Cold Regions Engineering, vol. 15, pp. 17-33.

Pruppacher, HR \& Klett, JD 2010, 'Equilibrium between water vapor, water, aqueous solutions, and ice in bulk', in Microphysics of Clouds and Precipitation, second ed., Springer, Berlin, pp. 100-125.

Ptak, M \& Nowak, B 2017, 'Zmiany temperatury wody w Prośnie w latach 1965-2014' ['Changes in water temperature in Prosna river in 1965-2014'], Woda-Środowisko-Obszary Wiejskie, vol. 17, no. 3, pp. 101-112.

Searcy, JK \& Hardison, CH 1960, 'Double-Mass Curves', Geological Survey Water-Supply Paper, vol. 1541B. Available from: <http://udspace.udel.edu/ handle/19716/1592>. [4 April 2020].

Sen, A \& Srivastava, M, 1990, 'Regression Analysis Theory, Methods, and Applications', Springer-Verlag, New York.

Shen, H, Cunderlik, J, Godin, G, Coombs, A, Rimer, A \& Dobrindt, I 2014, 'Thermal effects of the proposed water reclamation centre discharge on the east Holland river', Journal of Water Management Modeling, vol. 22, Available from: <https:// www.chijournal.org/C366>. [4 April 2020].

Steele, TD, Gilroy, EJ \&Hawkinson, RO 1974, 'Techniques for the assessment of areal and temporal variations in streamflow quality', U.S. Geological Survey Open-File Report, Washington, D.C

Takács, K, Kern, Z \& Nagy, B 2013, 'Impacts of anthropogenic effects on river ice regime: Examples from Eastern Central Europe', Quaternary International, vol. 293, pp. 275-282.

Taylor, CH \& Loftis, JC 1989, 'Testing for trend in lake and groundwater quality time series', 'Water Resources Bulletin', vol. 25, no. 4, pp. 715-726.

van Belle, G \& Hughes, JP 1984, 'Nonparametric tests for trend in water quality', 'Water Resource Research', vol. 20, no. 1, pp. 127-136.

Wright S, 1921, 'Correlation and causation', 'Journal of Agricultural Research' vol. 20, pp. 557-585.

Wrzesiński, D 2016, 'Use of entropy in the assessment of uncertainty of river runoff regime in Poland', Acta Geophysica, vol. 64, no. 5, pp. 1825-1839.

Yang, X, Pavelsky, TM \& Allen, GH 2020, 'The past and future of global river ice', Nature, vol. 577, pp. 69-73.

Yu, YS, Zou, S \& Whittemore, D 1993, 'Non-parametric trend analysis of water quality data of river in Kansas', Journal of Hydrology, vol. 150, pp. 61-80.

Yue, S \& Hashino, M 2003, 'Long term trends of annual and monthly precipitation in Japan', JAWRA Journal of the American Water Resources Association, vol. 39, no. 3, pp. 587-596.
Yue, S \& Wang, C 2004, 'The Mann-Kendall Test modified by effective sample size to detect trend in serially correlated hydrological series', Water Resources Management, vol. 18, pp. 201-218.

Yue, S \& Wang, CY 2002, 'The applicability of pre-whitening to eliminate the influence of serial correlation on the MannKendall test', Water Resource Research, vol. 38, no. 6, pp. 4-17.

Zetterqvist, L 1991, 'Statistical estimation and interpretation of trends in water quality time series', Water Resource Research, vol. 27, no. 8, pp. 1637-1648. 